\title{
PENGEMBANGAN MEDIA PEMBELAJARAN BANGUN RUANG SISI DATAR BERBASIS ADOBE FLASH PROFESSIONAL CS5
}

\author{
${ }^{1)}$ Haniek Sri Pratini, ${ }^{2}$ EIfrieda Yapita Rethmy Prihatini \\ Pendidikan Matematika Fakultas Keguruan dan Ilmu Pendidikan Universitas Sanata Dharma \\ ${ }^{1}$ haniek_sp@usd.ac.id
}

\begin{abstract}
Received : $29 / 10 / 2019$

This research is motivated by the lack of use of learning media that accommodates students' desires about learning mathematics that is fun and

Accepted : 29/01/2020

Published : 31/01/2020 makes it easier for teachers to deliver the material. This study aims to determine the ways and impacts of developing learning media to build flat side spaces based on adobe flash professional cs5. This research includes development research (research and development). The development research procedure used is the modification of the borg and gall development model and the sugiyono development model, which includes five development steps: (1) preliminary studies, (2) development of instructional media, (3) product validation, (4) trial instruments limited, and (5) limited trials. The subjects of this study were students of class viii in one of the state junior high schools in yogyakarta. The object of this research is the learning media to build flat side space based on adobe flash professional CS5. Data collection techniques used were questionnaires, observations, interviews and documentation. The results of this study are in the form of learning media to build flat side space based on adobe flash professional CS5. Media quality is included in the category of "very good" with an percentage of ideals of $86.36 \%$. The resulting learning media, gives an overview to teachers about the development of learning media based on adobe flash professional CS5. Students are more active and enthusiastic in learning processes and increase student learning outcomes by $67.31 \%$ based on the results of the pretest and posttest.
\end{abstract}

Keywords: Development, Learning Media, Adobe Flash Professional CS5, Geometry flat side space.

\begin{abstract}
Abstrak
Penelitian ini dilatar belakangi oleh minimnya pemanfaatan media pembelajaran yang mengakomodasi keinginan siswa tentang pembelajaran matematika yang menyenangkan dan memudahkan guru menyampaikan materi. Penelitian ini bertujuan mengetahui cara dan dampak dari pengembangan media pembelajaran bangun ruang sisi datar berbasis Adobe Flash Professional CS5. Penelitian ini termasuk penelitian pengembangan (Research and Development). Prosedur penelitian pengembangan yang digunakan adalah hasil modifikasi dari model pengembangan Borg and Gall dan model pengembangan Sugiyono, yang meliputi lima langkah pengembangan: (1) studi pendahuluan, (2) pengembangan media pembelajaran, (3) validasi produk, (4) instrumen uji coba terbatas, dan (5) uji coba terbatas. Subjek penelitian ini adalah siswa kelas VIII di salah satu SMP negeri di Yogyakarta. Objek pada penelitian ini adalah media pembelajaran bangun ruang sisi datar berbasis Adobe Flash Professional CS5. Teknik pengumpulan data yang digunakan adalah kuesioner, observasi, wawancara dan dokumentasi.Hasil penelitian ini berupa media pembelajaran bangun ruang sisi datar berbasis Adobe Flash Professional CS5. Kualitas media termasuk kategori "Sangat Baik" dengan presentase keidealan sebesar 86,36 \%. Media pembelajaran yang dihasilkan, memberikan gambaran kepada guru tentang pengembangan media pembelajaran berbasis Adobe Flash Professional CS5. Siswa lebih aktif dan antusias dalam peoses pembelajaran dan meningkatkan hasil belajar siswa sebesar 67,31\% berdasarkan hasil pretest dan posttest.
\end{abstract}

Kata Kunci: Pengembangan, Media pembelajaran, Adobe Flash Professional CS5, Bangun ruang sisi datar

\section{Pendahuluan}

Pembelajaran matematika umumnya dilakukan dengan metode ceramah yang dikombinasi dengan latihan soal atau sering disebut metode konvensional. Metode ini 
cenderung membosankan dan tidak menarik minat siswa. Pada intinya, pembelajaran matematika seharusnya bertujuan untuk melatih siswa berpikir sistematis, logis, kritis dan kreatif dalam menemukan ide ataupun kemampuan memecahkan masalah (Susanto, 2013: 183). Pemiilihan strategi dan metode pembelajaran serta pemanfaatan perangkat pembelajaran yang sesuai dengan materi yang disampaikan akan membangkitkan minat dan ketertarikan siswa.

Selain itu, pengelompokan kelas belajar terkadang tidak berdasarkan kemampuan siswa, sehingga dalam setiap kelasnya akan ada beragam kemampuan dan kecerdasan yang mempengaruhi untuk memahami materi yang diberikan. Hal lainnya yang mendukung penelitian ini adalah adanya materi tertentu dalam pembelajaran matematika yang membutuhkan alat bantu lain sehingga mempermudah pemahaman akan materi tersebut.

Berdasarkan beberapa hal tersebut dibutuhkan kombinasi antara metode pembelajaran yang menarik dan mengakomodasi semua tingkat kemampuan siswa serta mempermudah guru menyampaikan materi yang dibutuhkan. Hal tersebut dapat dipenuhi oleh media pembelajaran yang dikombinasikan dengan kemajuan teknologi untuk menciptakan pembelajaran yang tidak hanya menarik tetapi juga meningkatkan pemahaman siswa. Media pembelajaran merupakan alat yang memungkinkan siswa untuk mengerti dan memahami sesuatu dengan mudah (Arsyad. 2002). Kemajuan teknologi, mampu mendukung terciptanya media pembelajaran yang memuat semua konten yang mendukung tersampaikannya materi yang sulit dijelaskan dengan metode ceramah seperti materi bangun ruang sisi datar.

Pengembangkan media pembelajaran bangun ruang sisi datar berbasis Adobe Flash Professional CS5 didasarkan pada studi pendahuluan yang dilakukan kemudian divalidasi oleh ahli, menyiapkan instrumen pendukung, dan diuji cobakan. Setelah peneltian dilakukan dapat dilihat kualitas media yang dihasilkan dan dampak dari pengembangan media pembelajaran tersebut.

Permasalahan dalam penelitian adalah: 1) Bagaimanakah pengembangan media pembelajaran bangun ruang sisi datar berbasis Adobe Flash Professional CS5?, dan 2) Bagaimanakah deskripsi dampak penggunaan media pembelajaran bangun ruang sisi datar berbasis Adobe Flash Professional CS5? Sedangkan tujuan dalam penelitian ini adalah: 1) Untuk mengembangan media pembelajaran bangun ruang sisi datar berbasis Adobe Flash Professional CS5, dan 2) Untuk mendeskripsi dampak penggunaan media pembelajaran bangun ruang sisi datar berbasis Adobe Flash Professional CS5. 
Media pembelajaran menurut Hamdani (2011), Gerlach dan Ely (dalam Arsyad, 2011) adalah alat yang digunakan untuk merangsang dan meningkatkan minat belajar siswa sehingga pembelajaran menjadi menyenangkan dengan interaksi positif dan dapat mencapai tujuan pembelajaran yang diinginkan. Selain itu, menurut Sudjana dan Rivai (2005) media pembelajaran bermanfaat untuk meningkatkan motivasi belajar siswa karena pembelajaran yang lebih menarik, bahan pelajaran yang diberikan menjadi lebih jelas sehingga mudah dipahami siswa. Media pembelajaran yang dikembangkan adalah software Adobe Flash Professional CS5 menjadi suatu media pembelajaran yang interaktif.

Adobe Flash Professional CS5 adalah program pembuat animasi yang menarik dan inovatif, biasanya digunakan untuk membuat tampilan web yang menarik. Software ini digunakan oleh berbagai kalangan untuk membuat animasi pada halaman website, profil perusahaan, CD interaktif, game, dll. Saat ini penggunaannya telah berkembang untuk pembuatan game di mobile device. Animasi membuat tampilan presentasi semakin menarik.

Menurut Kusrianto (2006), terdapat beberapa fitur baru pada Adobe Flash Professional, yaitu: 1) tool-tool yang lebih ekspresif, 2) filter-filter, 3) blend mode, 4) bitmap yang mulus, 5) anti alias pada teks, 6) video encoder, yang berfungsi untuk mengkonversi file video ke flash video (FLV). Program Adobe Flash Professional CS 5 dijalankan melalui langkah-langkah menurut Andi (2011), yaitu: 1) Double klik pada icon program Adobe Flash Professional,CS 5, 2) Klik Start $\rightarrow$ All programs $\rightarrow$ Adobe $\rightarrow$ Adobe Flash Professional CS 5 sehingga tampil welcome screen seperti pada Gambar 1 berikut.

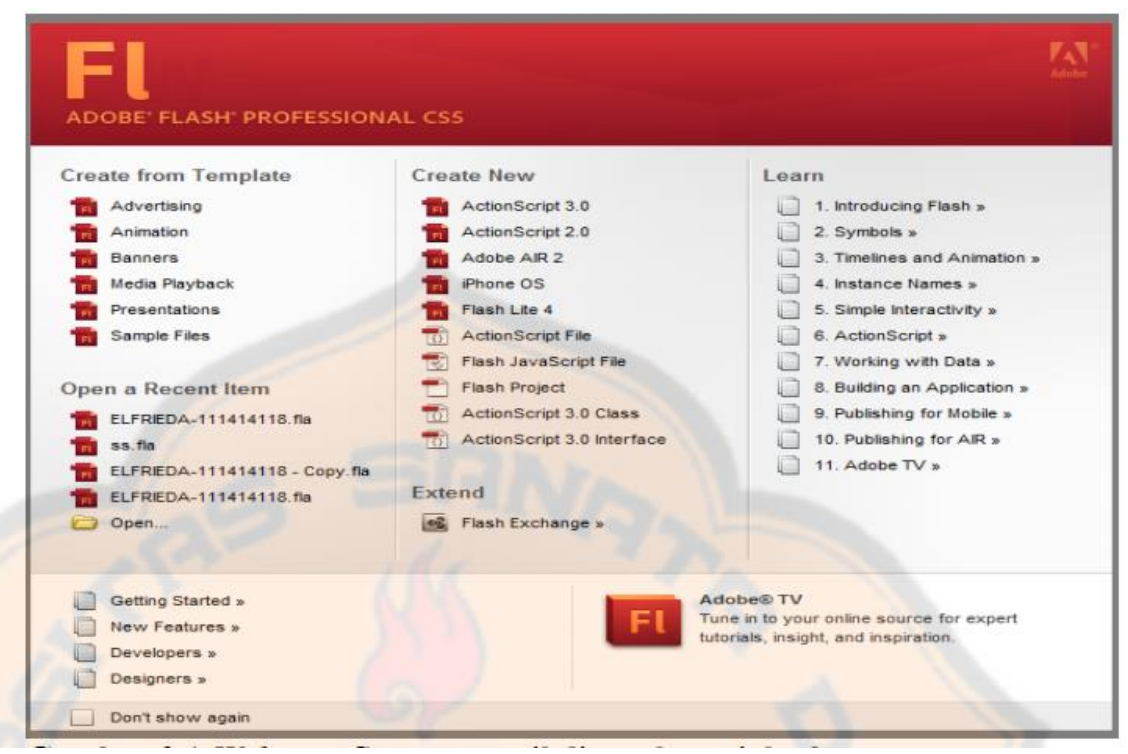


Gambar 1. Welcome screen tampil di awal menjalankan program

Jendela welcome screen menyediakan 4 pilihan untuk memulai Adobe Flash Professional CS 5, yaitu:

1) Create from template, memulai program dengan membuka lembar kerja menggunakan template yang disediakan.

2) Open a recent item, memulai program dengan membuka kembali file yang pernah disimpan atau pernah dibuka sebelumnya.

3) Create new, memulai program dengan membuat lembar kerja baru disertai beberapa script yang tersedia.

4) Learn, memulai program dengan membuka jendela Help yang berguna untuk mempelajari suatu perintah.

Jendela welcome dapat dinonaktifkan dengan meng-klik kotak don't show again yang terdapat pada sisi bawah jendela welcome screen sehingga ketika menjalankan program maka akan tampil lembar kerja pada Gambar 2 berikut.

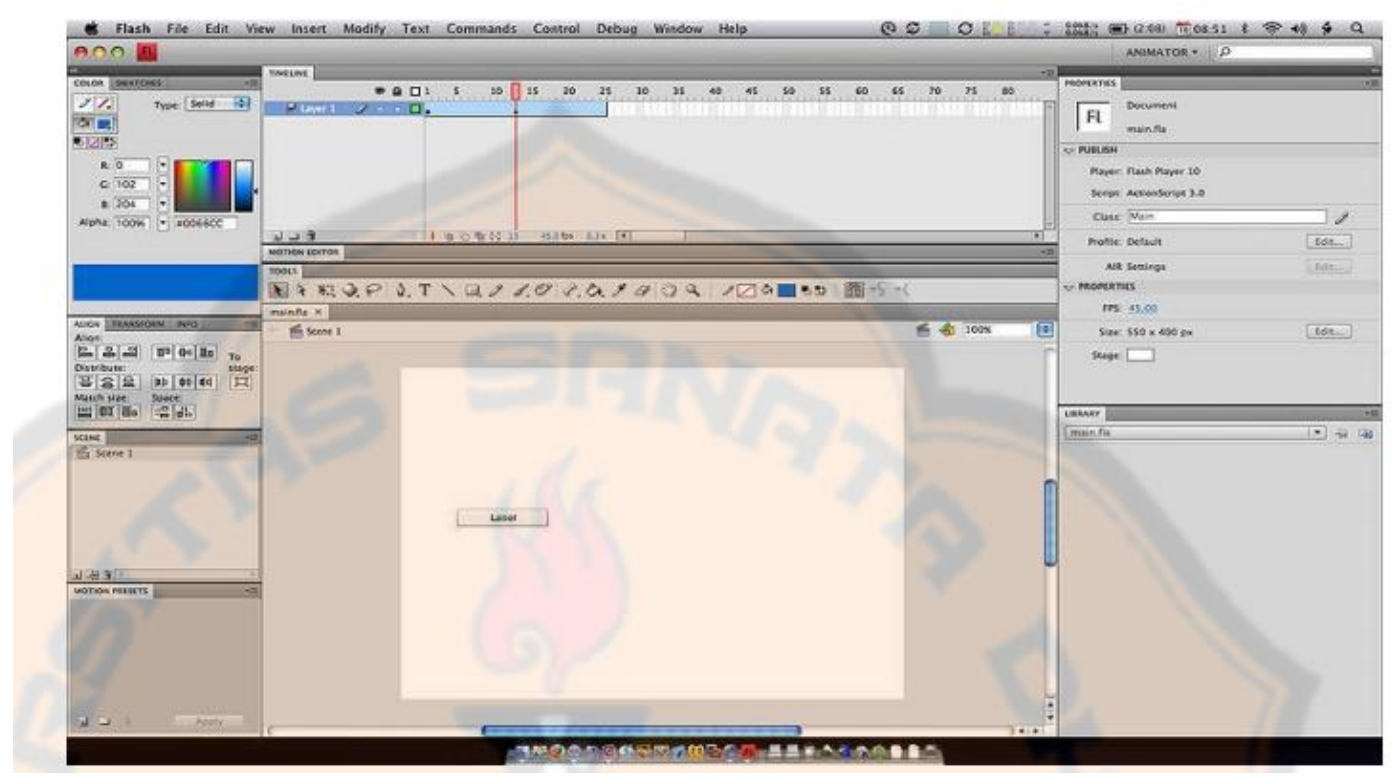

Gambar 2. Jendela Program Adobe Flash Professional CS 5

Salah satu topik pembelajaran geometri SMP adalah Bangun Ruang Sisi Datar, yang meliputi: balok, kubus, prisma, dan limas. Topik tersebut dikemas dalam kompetensi dasar: Memahami sifat dan unsur bangun ruang, dan menggunakannya dalam pemecahan masalah. 
Topik ini dipilih karena merupakan salah satu materi yang dianggap sulit oleh siswa SMP. Materi ini juga sesuai untuk dikembangkan dengan menggunakan media pembelajaran berbasis Adobe Flash Professional CS 5.

Pemilihan materi ini juga didukung oleh penelitian yang dilakukan oleh Yusuffia (2014) yang mengembangkan media pembelajaran interaktif matematika berbasis pendidikan karakter dengan software adobe flash CS 3 pada pokok bahasan Teorema Pythagoras. Pengembangan dengan menggunakan model ADDIE ini dilakukan dalam 5 tahap, yaitu 1) analisis kurikulum, materi, teknologi dan situasi, 2) perencanaan terhadap penyiapan referensi, penyusunan materi isi dan penyusunan story board, 3) pengembangan dalam membuat komponen media yang dikemas dalam bentuk CD kemudian divalidasi, 4) implementasi dalam ujicoba kelas kecil dan ujicoba kelas besar, dan 5) evaluasi oleh ahli media, ahli materi, guru, dan siswa. Kualitas media yang dihasilkan termasuk dalam kategori baik dan layak dengan persentase keidealan 99,63\% dan respon positif yang diberikan siswa dengan rata-rata persentase keseluruhan $71,07 \%$.

Penelitian juga didukung penelitian yang dilakukan oleh Alief (2014) yang mengembangkan media pembelajaran matematika berbasis pendidikan kare=akter menggunakan macromedia flash professional 8 pada pokok bahasan Aritmetika Sosial kelas VII dengan model pengembangan Borg \& Gall. Model ini terdiri dari 3 tahap, yaitu: 1) perencanaan yang meliputi: studi pustaka dan penentuan media yang akan dikembangkan, 2) pengembangan yang meliputi: penentuan materi, penyusunan story board, penyusunan medi dan instrument penelitian, dan 3) penilaian yang meliputi: ujicoba terbatas, ujicoba kelas kecil, ujicoba kelas besar. Kualitas media yang dihasilkan termasuk dalam kategori baik dan layak dengan persentase keidealan $83,90 \%$ dan respon siswa terhadap media pembelajaran adalah sangat baik dengan persentase keseluruhan $87 \%$.

Selain itu penelitian juga didukung penelitian yang dilakukan oleh Rifki (2014) yang mengembangkan media pembelajaran berbasis CD interaktif dengan adobe flash professional CS 5 pada pokok bahasan Bilangan Bulat SMP kelas VII dengan metode pengembangan modifikasi desain 4-D yang terdiri dari Define, Design, Develop, dan Disseminate. Hasil penelitian menunjukkan bahwa rata-rata nilai kelas eksperimen lebih baik dar rata-rata nilai kelas control, sehingga dapat disimpulkan bahwa penggunaan media CD interaktif dengan aplikasi adobe flash professional CS 5 lebih baik dari siswa yang menggunakan CD interaktif sebelumnya.

\section{Metode Penelitian}


Jenis penelitian yang digunakan adalah penelitian dan pengembangan (Research and Development). Model pengembangan yang digunakan adalah modifikasi dari pengembangan Sugiyono (2012) dan Borg \& Gall (Sukmadinata, 2011) sebagai berikut.

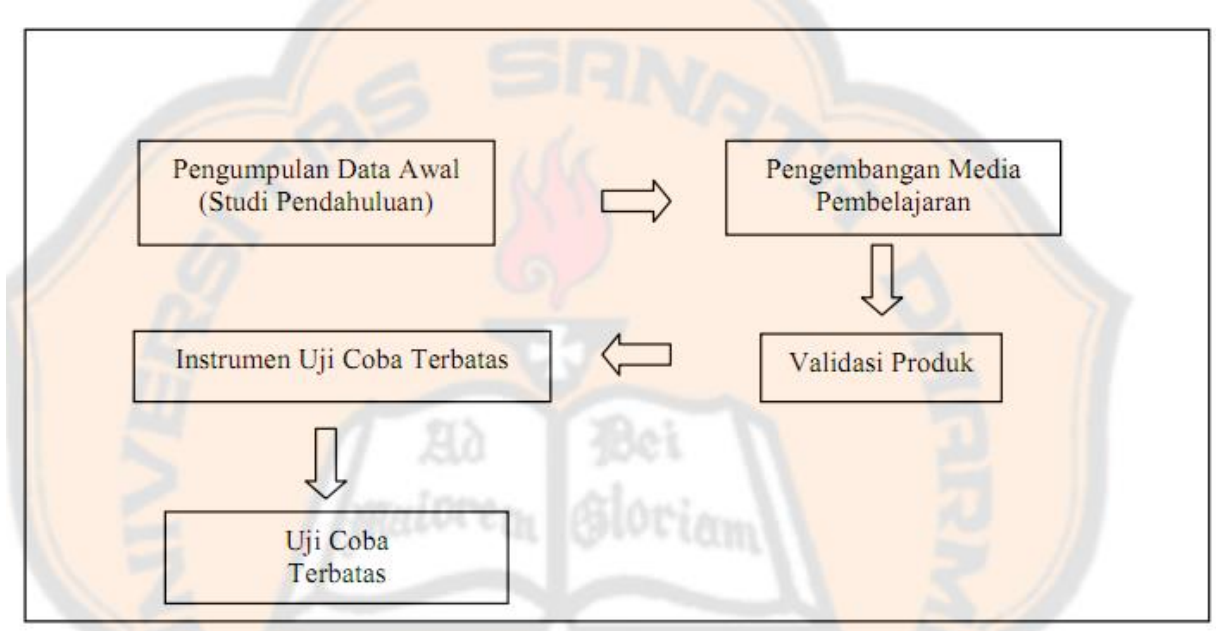

Gambar 3. Model Desain Pengembangan Produk

Tahapan pengembangan diawali dengan tahap studi pendahuluan melalui analisis potensi dan masalah yang ditemui dalam observasi awal. Studi ini menghasilkan deskripsi temuan awal sebelum penelitian serta kajian literatur terkait untuk mendukung inovasi media pembelajaran berbasis teknologi.

Tahap kedua adalah tahap pengembangan media pembelajaran sebagai produk pengembangan. Tahap ini menggunakan langkah pengembangan dari Borg and Gall (Sukmadinata, 2011) yaitu perencanaan dan pengembangan produk. Produk yang dihasilkan berupa media pembelajaran yang matematika dengan memanfaatkan Adobe Flash Professional CS5. Langkah awal penelitian ini dengan melakukan identifikasi indikator dan tujuan pembelajaran yang akan dicapai kemudian menyusun storyboard dan mengembangkan media yang memuat semua konten pendukung.

Tahap tiga adalah validasi produk yang mengambil langkah dari Sugiyono (2012) yaitu memvalidasi produk yang dihasilkan. Validasi dilakukan oleh ahli atau pakar yang berpengalaman dibidangnya. Hasil validasi dari para ahli berupa data kualitatif berupa komentar dan saran dari para ahli dan kuantitatif berupa penilaian ahli untuk menentukan kualitas media. Data tersebut dijadikan acuan untuk melakukan revisi pada media sebelum diuji cobakan.

Tahap empat yaitu pengembangan instrumen yang dibutuhkan untuk uji coba terbatas. Instrumen yang belum terstandar divalidasi terlebih dahulu kepada para ahli sedangkan untuk instrumen soal tes divalidasikan kepada siswa kelas IX di sekolah tempat peneltian. Validasi dan revisi dilakukan sebelum digunakan pada tahapan selanjutnya. 
Tahap kelima yaitu uji coba terbatas yang menggunakan tahapan pengembangan hasil modifikasi dari Sugiyono (2012) dan Borg \& Gall (Sukmadinata, 2011). Tahap ini dilakuakn setelah produk dan instrumen selesai divalidasi dan direvisi. Tahapan diawali dengan pemberian soal pretest kemudian pembelajaran dengan menggunakan produk lalu diakhiri dengan postetest. Selain itu juga dilakukan wawancara kepada guru dan siswa serta pengisian angket penilaian media oleh pengguna.

Teknik pengumpulan data penelitian menggunakan wawancara, observasi, penyebaran kuesioner, tes, dan dokumentasi ujicoba hasil pengembangan. Instrument penelitian sesuai dengan teknik pengumpulan datanya adalah: pedoman wawancara, pedoman/lembar observasi, kuesioner, soal tes, dan alat perekam.

Teknik analisis data dibedakan menjadi 2, yaitu analisis data kuantitatif dan kualitatif. Analisis data kuantitatif digunakan untuk menganalisis data hasil wawancara, sedangkan untuk analisis data kuantitatif digunakan untuk menganalisis data hasil observasi, hasil kuesioner, dan hasil tes.

\section{Hasil dan Pembahasan}

Bagian ini menjelaskan tahapan awal prosedur pengembangan yang memuat situasi pembelajaran di sekolah terkait penggunaan media pembelajaran yang ditunjukkan melalui penggalian potensi dan masalah. Selama proses pengumpulan data awal, peneliti menemukan bahwa guru memiliki keinginan yang cukup tinggi untuk melakukan uinovasi pada proses pembelajaran di kelas, seperti pada metode mengajar ataupun penggunaan perangkat pembelajaran secara efektif. Namun, pada pelaksanaanya, guru lebih memilih menggunakan metode ceramah dan dianggap sebagai metode yang paling efektif. Hal ini, dikarenakan keterbatasan waktu, sumber daya yang kurang memadai dan juga minimnya pelatihan mengenai pemanfaatan media pembelajaran. Sedangkan dari sisi siswa, tergolong dalam siswa yang cukup aktif dalam pembelajaran jika menggunakan metode pembelajaran yang inovatif dan menyenangkan. Mempertimbangkan potensi dan masalah yang ada, perlu dicari metode pembelajaran yang inovatif dan mengakomodasi potensi yang ada. Penerapan inovasi pembelajaran diasumsikan akan meningkatkan minat belajar siswa dan membantu guru untuk menyampaikan materi dengan lebih mudah. Pada tahap ini, menyediakan instrumen wawancara untuk memperdalam temuan awal yang telah ada tentang kebutuhan guru dan siswa dalam pembelajaran dengan wawancara. Tahapan ini juga mempertimbangkan hasil observasi pembelajaran di kelas yang berpedoman pada lembar observasi pada buku pedoman PPL FKIP USD tahun 2013. 
Pada tahapan studi pendahuluan diperoleh data hasil wawancara yaitu: guru cenderung untuk menggunakan perangkat pembelajaran yang sama setiap tahunnya tanpa mempertimbangkan perbedaan karakteristik siswa yang berbeda dan lebih memilih menggunakan metode pembelajaran konvensional. Selain itu, media pembelajaran sangat jarang sekali digunakan, bahkan untuk pembelajaran berbasis multimedia tidak pernah digunakan oleh guru. Hal tersebut dikarenakan, minimnya kemampuan guru untuk berinovasi dengan media serta sangat jarang ada penelitian terkait media pembelajaran. Sedangkan dari sisi siswa, rata-rata tidak menyiapkan diri sebelum pembelajaran, siswa merasa pembelajaran sangat membosankan dan kondisi kelas cukup ramai yang menurunkan konsentrasi. Siswa menginginkan pembelajaran yang menyenangkan dan menarik sehingga bisa mempelajari matematika dengan perasaan senang.

Berdasarkan observasi yang dilakukan di dua kelas sebanyak masing-masing dua kali, diperoleh bahwa kategori kemampuan guru dalam proses pembelajaran yaitu "Cukup". Dengan rata-rata penilaian pada masing-masing kelas yaitu 5,89 dan 5,65. Peneliti melihat secara khusus beberapa hal yang cukup krusial yaitu guru tidak menggunakan media pembelajaran sekalipun tersedia fasilitas yang mendukup penggunaan media pembelajaran. Selain itu, suasana kelas cenderung ramai dan sedikit tidak terkontrol karena siswa yang mengobrol dengan temannya pada saat mengerjakan soal ataupun diskusi kelas.

Prosedur pengembangan produk dilakukan dengan kajian literatur untuk menentukan isi produk sehingga sesuai dengan indikator dan tujuan pembelajaran yang akan dicapai. Penyusunan produk juga didasari dari hasil wawancara dan observasi sehingga produk yang dihasilkan mampu mengakomodasi potensi dan menyelesaikan masalh yang ada. Tahapan berikutnya adalah menyusun storyboard sehingga mempermudah penyusunan dan pengembangan media pembelajaran serta konten-konten multimedia yang dibutuhkan. Selanjutnya, melakukan pengembangan media pembelajran yang memuat konten video, teks, gambar, suara dan juga soal tes interaktif bagi siswa.

Tahap selanjutnya adalah validasi produk yang dilakukan sebelum produk diuji cobakan, yaitu: Instrumentasi persiapan uji coba, validasi produk, dan revisi produk

Tahap berikutnya adalah ujicoba terbatas. Tahap ini dilakukan sebanyak 6 kali pertemuan dengan alokasi waktu setiap pertemuan selama 40-80 menit. Setelah melakukan uji coba terbatas, peneliti membandingkan nilai pretest dan postest siswa untuk melihat presentase perubahan nilai sebagai dampak dari penggunaan media pembelajaran. Rerata nilai pretest yang diperoleh sebesar 45,67 dan rerata nilai postest yang diperoleh sebesar 74,83 dengan presentase perubahan nilai sebesar $67,31 \%$. Selain itu, berdasarkan penilaian dari pengguna (siswa) terhadap penggunaan media dari 6 kriteria sebesar 3,04 termasuk kategori 
"Sangat Baik" dengan rentang nilai SB $\geq 3$ dan presentase keidealan sebesar $76 \%$. Peneliti melakukan wawancara setelah uji coba untuk mengetahui dampak penggunaan media. Berdasakan hasil wawancara dengan guru diperoleh bahwa guru memiliki gambaran model pengembangan media pembelajaran matematika yang sesuai untuk materi bangun ruang sisi datar, dan guru mengetahui manfaat dari penggunaan media pembelajaran dalam proses pembelajaran di kelas seperti meningkatkan minat siswa dan pembelajaran menjadi menyenangkan. Sekalipun demikian, guru masih kesulitan untuk proses pembuatan media berbasis teknologi.

Berdasarkan hasil penelitian tersebut, telah menjawab dua rumusan masalah yang ada yaitu bahwa: pengembangan produk telah dilakukan berdasarkan tahapan pengembangan yang ada dan diperoleh bahwa kuliatas media berdasarkan penilaian semua ahli termasuk dalam kategori "Sangat Baik" dan hal tersebut menunjukan bahwa produk yang dihasilkan sangat layak untuk diujicobakan, begitupun untuk semua instrumen penelitian telah melalui tahapan validasi dan layak untuk digunakan.

Dampak dari penggunaan produk yang dihasilkan adalah membantu guru memberikan gambaran tentang pengembangan media pembelajaran, meningkatkan hasil pembelajaran siswa sebesar 67,31 \% berdasarkan hasil pretest dan posttest. Penggunaan media pembelajaran juga mendapatkan respon positif dari pengguna sebesar 86,36\%. Beberapa hal tersebut menunjukan bahwa media pembelajaran yang dikembangkan efektif untuk digunakan dalam pembelajaran.

Pembahasan dari hasil penelitian dan pengembangan media pembelajaran ini berusaha menjawab rumusan masalah yang diajukan. Rumusan masalah pertama adalah: Bagaimana pengembangan media pembelajaran matematika berbasis Adobe Flash Professional CS 5 pada pokok bahasan Bangun ruang Sisi Datar kelas VIII?. Berdasarkan analisis mengenai kebutuhan akan media pembelajaran yang membantu guru menjelaskan materi dan membantu siswa untuk lebih mudah dalam memahami materi yang ada, peneliti mengembangkan media pembelajaran dengan memenfaatkan software Adobe Flash Professional CS 5. Hal pertama yang dilakukan adalah studi pendahuluan untuk menemukan masalah yang muncul dalam proses pembelajaran melalui wawancara dan observasi. Hasilnya adalah bahwa siswa menginginkan metode mengajar yang tidak hanya membantu memahami materi tetapi juga menciptakan suasana pembelajaran yang menyenangkan. Pengembangan media pembelajaran yang dilakukan adalah yang memuat semua konten multimedia yang bermanfaat bagi pembelajaran seperti: teks, suara, gambar, video, animasi, dan soal interaktif. Materi mengacu pada buku guru, buku siswa dan sumber-sumber lain yang terkait dengan materi yang diajarkan. Langkah selanjutnya adalah menyusun storyboard yang akan memudahkan dalam 
proses pembuatan media. Langkah terakhir adalah menyusun media pembelajaran dengan berpedoman pada storyboard yang ada dan konten-konten terkait materi yang akan dimasukkan ke dalam media pembelajaran. Hasil penilaian produk media pembelajaran memperoleh nilai 304 dengan persentase keidealan sebesar 86,36\% dan termasuk aktegori "Sangat Baik" sehingga layak untuk diujicobakan. Namun terdapat juga masukan untuk memperbaiki beberapa hal pada media dari validator. Revisi terhadap media pembelajaran meliputi: tata letak, penggunaan warna, ukuran dan fungsi navigasi. Selain itu juga terdapat revisi pada materi yang meliputi: definisi, penulisan, symbol, tanda dan gambar. Produk media yang dihasilkan adalah: 1) frame pembuka, 2) petunjuk, 3) materi, 4) latihan soal dan 5) evaluasi. Produk media pembelajaran tersebut memuat hampir semua konten multimedia seperti teks, gambar, suara, video, animasi, dan soal interaktif.

Rumusan masalah kedua adalah: Bagaimana dampak pengembangan media pembelajaran berbasis Adobe Flash Professional CS 5? Ujicoba terbatas dilakukan setelah produk direvisi sesuai saran validator/ahli. Ujicoba dilakukan pada 32 orang siswa kelas VIII di sekolah penelitian. Penggunaan media pembelajaran dalam proses belajar mengajar ternyata memberikan dampak tidak saja pada siswa tetapi juga pada guru. Dampak pada siswa dalah ketertarikan dan antusiasme siswa saat pembelajaran berlangsung. Siswa aktif mengikuti pembelajaran dan mengerjakan semua latihan soal dengan semangat. Selain itu siswa juga aktif bertanya. Setelah 6 pertemuan pembelajaran siswa mengerjakan soal posttest. Hasil tes menunjukkan adanya peningkatan hasil belajar sebesar $67,31 \%$ setelah dilakukannya pembelajaran dengan media berbasis Adobe Flash Professional CS 5. Hasil kuesioner juga menunjukkan hasil "Sangat Baik" dengan skor 3.04 dan persentase keidealan 76\%. Dampak bagi guru adalah bertambahnya referensi media pembelajaran berbasis Adobe Flash

\section{Professional CS 5}

\section{Kesimpulan}

Penelitian yang dilakukan adalah research and development dengan topik pengembangan media pembelajaran matematika berbasis Adobe Flash Professional CS 5 pada materi Bangun Ruang Sisi Datar kelas VII. Berdasarkan hasil penelitian yang dilakukan dapat disimpulkan bahwa:

1. Peneliti dengan memanfaatkan software Adobe Flash Professional CS 5 untuk menghasilkan media pembelajaran dengan prosedur pengembangan dengan yang telah dimodifikasi. Prosedur pengembangan meliputi: a) Studi Pendahuluan dengan melakukan pengamatan tentang situasi pembelajaran di sekolah dan menganalisis potensi serta masalah yang ada untuk menjadi acuan dalam proses pengembangan produk; b) 
Pengembangan Media Pembelajaran melalui merancang produk yang sesuai berdasarkan tahapan sebelumnya berupa media pembelajaran berbasis Adobe Flash Professional CS5. Produk tersebut memuat konten-konten multimedia yang bermanfaat dalam pembelajaran; c) Validasi Produk dengan melakukan validasi terhadap media pembelajaran sebelum digunakan dalam uji coba terbatas. Kualitas media pembelajaran sebesar 3,04 dalam kategori "Sangat Baik" dengan presentase keidealan sebesar 86,36 \%. Penilaian produk berdasarkan penilaian masing-masing ahli adalah "Sangat Baik" dengan nilai 96 dan presentase keidealan sebesar 85,71 \% untuk ahli media, menurut ahli materi adalah "Sangat Baik" dengan nilai 67 dan presentase keidealan sebesar 88,71\% serta menurut ahli pembelajaran adalah "Sangat Baik" dengan nilai 141 dan presentase keidealan 85,98 $\%$; d) Instrumentasi Uji Coba Terbatas dengan menyiapkan instrumen yang akan digunakan dalam proses uji coba terbatas berupa wawancara, kuesioner serta soal tes yang semuanya telah divalidasi terlebih dahulu oleh ahlinya; e) Uji Coba Terbatas terhadap instrumen yang telah disiapkan serta produk yang dihasilkan, akan diuji cobakan secara langsung kepada subjek penelitian.

2. Dampak dari penggunaan media pembelajaran bagi siswa adalah meningkatkan prestasi belajar sebesar $67,31 \%$. Penggunaan media pembelajaran mendapatkan respon positif dari pengguna sebesar 86,36 \%. Sedangkan dampak penggunaan media pembelajaran matematika tersebut bagi guru adalah memiliki gambaran model pengembangan media pembelajaran matematika yang sesuai untuk materi bangun ruang sisi datar, dan metode pembelajaran yang menyenangkan.

Saran yang dapat disampaikan terkait hasil penelitian dan kesimpulan adalah perlunya mengembangkan kemampuan bagi para guru, agar dapat memfasilitasi pembelajaran menggunakan media pembelajaran berbasis Adobe Flash Professional CS 5. Para guru haruslah memampukan diri agar memiliki bahasa yang sama dengan siswa dalam mengembangkan pembelajaran.

\section{Pustaka}

Arsyad, Ashar. 2002. Media Pembelajaran. Jakarta: PT. Grafindo Persada.

Kusrianto, Adi. 2002. Panduan Lengkap Memakai Macromedia Flash Professional 8. Jakarta: PT. Elex Media Komputindo.

Sugiyono. 2010. Metode peneltian Kuantitatif, Kualitatif dan R\&D. Bandung: Alfabeda.

Sugiyono. 2011. Metode peneltian Kuantitatif, Kualitatif dan R\&D. Bandung: Alfabeda.

Sugiyono. 2012. Metode peneltian Kuantitatif, Kualitatif dan R\&D. Bandung: Alfabeda. 
$\delta$ ELT $\Delta$ Jurnal Ilmiah Pendidikan Matematika 132 Vol. 8 No. 1 Januari 2020 Hal $121-132$

Sukmadinata, Nana Syaodih. 2011. Metode penelitian Pendidikan. Bandung: Remaja Rosdakarya.

Susanto, A. 2013. Teori Belajar Dan Pembelajaran. Jakarta: Kencana Prenata Media Group. 